\title{
Spatio-temporal patterns of bacterioplankton production and community composition related to phytoplankton composition and protistan bacterivory in a dam reservoir
}

\author{
Karel Šimek ${ }^{1,2, *}$, Karel Horňák ${ }^{1}$, Jan Jezbera ${ }^{1}$, Jiří Nedoma ${ }^{1}$, Petr Znachor ${ }^{1}$, \\ Josef Hejzlar ${ }^{1,2}$, Jaromír Sed'a ${ }^{1,2}$
}

${ }^{1}$ Biological Centre of the Academy of Sciences of the Czech Republic, v.v.i., Institute of Hydrobiology, Na Sádkách 7, 37005 České Budějovice, Czech Republic

${ }^{2}$ Faculty of Science, University of South Bohemia, 37005 České Budějovice, Czech Republic

\begin{abstract}
Seasonal changes in the abundance and production of epilimnetic bacterioplankton, protistan abundance and bacterivory, and extracellular phytoplankton production (EPP) were studied at 3 sampling stations (DAM, MIDDLE and RIVER) located along the longitudinal axis of the canyon-shaped, meso-eutrophic Rímov reservoir (Czech Republic). We found that at the river inflow (RIVER) compared to lacustrine parts of the reservoir (MIDDLE and DAM), different sources of organic carbon and of bacterial mortality control bacterioplankton dynamics and community composition. At the RIVER site, EPP accounted for a negligible part of bacterial carbon demand, thus indicating the prominent role of allochthonous sources of organic substrates in the river inflow. In addition, protistan bacterivory removed there, on average, only $9 \%$ of bacterial production. In contrast, at the lacustrine MIDDLE and DAM stations, protistan bacterivory accounted for 47 and $78 \%$ of bacterial production, respectively. Moreover, at these stations EPP was an autochthonous source of organic carbon sufficient to meet bacterial carbon demand and EPP was tightly correlated with bacterial carbon demand (DAM, $r^{2}=0.589, p<0.005 ;$ MIDDLE, $r^{2}=0.716, p<0.001$ ). At the DAM site, we analyzed changes in EPP in relationship to phytoplankton community dynamics and found that cryptophytes were associated with EPP. Only 2 algal groups, cryptophytes in a spring-early-summer period and diatoms in a summer-fall period, clearly dominated the phytoplankton. Changes in phytoplankton composition were related to changes in bacterial community composition studied by means of group-specific rRNA-targeted oligonucleotide probes. A trend of increased proportions of certain bacterial groups, mainly of the genus-like R-BT065 subcluster of Betaproteobacteria, was detected for the periods of high EPP levels, dominated by cryptophytes. More than $52 \%$ of the seasonal variability in the abundance of the R-BT065 cluster was explained by changing EPP levels that indicated a tight taxon-specific algal-bacterial relationship.
\end{abstract}

KEY WORDS: Reservoir - Bacterioplankton composition and production - Protistan bacterivory Phytoplankton community · Extracellular phytoplankton production · Algal-bacterial relationships . Betaproteobacterial groups

Resale or republication not permitted without written consent of the publisher

\section{INTRODUCTION}

Dam reservoirs are used for a multitude of purposes and constitute the most important and numerous human-made aquatic ecosystems. Despite their obvious importance, considerably less attention has been paid to the role and functioning of pelagic microbial food webs in reservoirs compared to other unmanaged freshwater ecosystems, such as natural lakes (e.g. Riemann \& Søndergaard 1986, Berninger et al. 1991). Dam reservoirs and lakes differ in many important limnological characteristics. The most pro- 
nounced differences exist with regard to canyonshaped reservoirs, since they are spatially highly heterogeneous systems due to relatively short water retention times and often show pronounced longitudinal heterogeneity (Thornton et al. 1990). In reservoir systems, nutrient and organic matter loads in riverine input combined with morphology and hydraulic retention time of a reservoir are the major factors affecting downstream plankton succession, rates of biological processes and resulting water quality (Comerma et al. 2003, Mašín et al. 2003).

In common with other aquatic systems, microbial processes in reservoirs play key roles in organic matter transformation and nutrient cycling. Thus, identification of factors controlling bacterial production (BP), bottom-up (resources) or top-down (predation and virus lysis), has become one of the central issues of current reservoir limnology (e.g. Šimek et al. 1998, Gasol et al. 2002, Mašín et al. 2003). For example, the spatially and temporarily variable role of protistan bacterivory and viral lysis has been reported for different parts of several canyon-shaped reservoirs and has shown a broad range of impacts of the 2 mortality factors on bacterioplankton production and community dynamics (Jezbera et al. 2003, Weinbauer et al. 2003, Jardillier et al. 2004).

Regarding bottom-up controlling factors, more pronounced gradients in microbial and phytoplankton variables are to be expected when the inflow river water parameters, particularly nutrients and organic matter loads, differ markedly from those in the lacustrine parts of a reservoir (Gasol et al. 2002, Mašín et al. 2003, Šimek et al. 2005). The bottom-up factors constraining growth of various phylogenetic bacterioplankton groups in the canyon-shaped Rímov reservoir have been studied in short-term incubations in dialysis bags by transplanting water samples into reservoir areas that were differently resource-limited (Jezbera et al. 2005, Šimek et al. 2005, Horňák et al. 2006). This approach revealed that the population dynamics and maximum growth rates of distinct bacterioplankon groups in situ are significantly affected by phosphorus availability (Šimek et al. 2006). In contrast to phosphorus concentrations, bulk dissolved organic carbon (DOC) concentrations usually did not change significantly along the longitudinal axis of the reservoir. However, a trend of increasing primary production towards the lacustrine reservoir parts was detected (Mašín et al. 2003). Thus, apparently the nature of the DOC pool substantially changes, along with an increasing contribution of phytoplanktonderived easily utilizable organic substrates that account for a significant portion of extracellular phytoplankton production (EPP) (e.g. Baines \& Pace 1991, Sundh 1992).
The composition of EPP as a high-quality substrate pool for bacteria has been examined in both laboratory and field studies (e.g. Sundh 1992, Giroldo et al. 2007). Even so, it is not known which algal species are the major EPP producers, though tight species-specific algal-bacterial relationships have been suggested for naturally occurring bacterial-algal consortia (Lindström 2001, Grossart et al. 2005, Murray et al. 2007).

We conducted seasonal sampling at 3 sites along the longitudinal axis of the canyon-shaped Ř́mov reservoir to test the hypothesis that spatially different bottom-up and top-down factors control bacterioplankton dynamics and community composition. Specific attention was paid to the following questions: (1) Are the autochthonously produced organic substrates, measured as EPP, a carbon source sufficient to meet bacterioplankton carbon demand in different parts of the reservoir? (2) Which groups of phytoplankton are associated with EPP in the lacustrine part of the reservoir? (3) Are the seasonal shifts in bacterioplankton community composition in the lacustrine DAM area of the reservoir, studied using fluorescence in situ hybridization with rRNA oligonucleotide probes, relatable to the shifts observed in phytoplankton composition?

\section{MATERIALS AND METHODS}

Study site and sampling. The seasonal study was conducted in the canyon-shaped, meso-eutrophic Ř́mov Reservoir (South Bohemia, Czech Republic, $48^{\circ} 50^{\prime} 46.90^{\prime \prime} \mathrm{N}, 14^{\circ} 29^{\prime} 15.50^{\prime \prime} \mathrm{E}_{;} 470 \mathrm{~m}$ above sea level; area, $2.06 \mathrm{~km}^{2}$; volume, $34.5 \times 10^{6} \mathrm{~m}^{3}$; length, $13.5 \mathrm{~km}$; max. depth, $43 \mathrm{~m}_{\text {; }}$ mean depth, $16.5 \mathrm{~m}$; mean retention time, $100 \mathrm{~d}$; dimictic) with a typical well-pronounced downstream longitudinal gradient in various biological and chemical parameters (e.g. Jezbera et al. 2003, Mašín et al. 2003, Šimek et al. 2006). From March 29 to November 15, 2005, water samples were collected at $3 \mathrm{wk}$ intervals from a depth of $0.5 \mathrm{~m}$ at 3 experimental sites along the longitudinal profile of the reservoir (assigned as DAM, MIDDLE and RIVER; Fig. 1). Mean water retention time for the epilimnetic water layers for the period of stratification (May to early October) was $27 \mathrm{~d}$ (range 9 to $42 \mathrm{~d}$ ).

Within $\sim 30$ min of sampling, $5 \mathrm{l}$ of water from each site were carried in plastic containers to the laboratory for further processing with respective methods. However, subsamples for phytoplankton primary and extracellular production as well as BP were immediately supplemented by radioactive-labeled substrates for uptake rate measurements and then incubated in situ.

Bacterial abundance and sizing. Samples were fixed with formaldehyde ( $\%$ final concentration, vol $/ \mathrm{vol})$, stained with DAPI (final concentration $0.2 \% \mathrm{wt} / \mathrm{vol}$ ) 


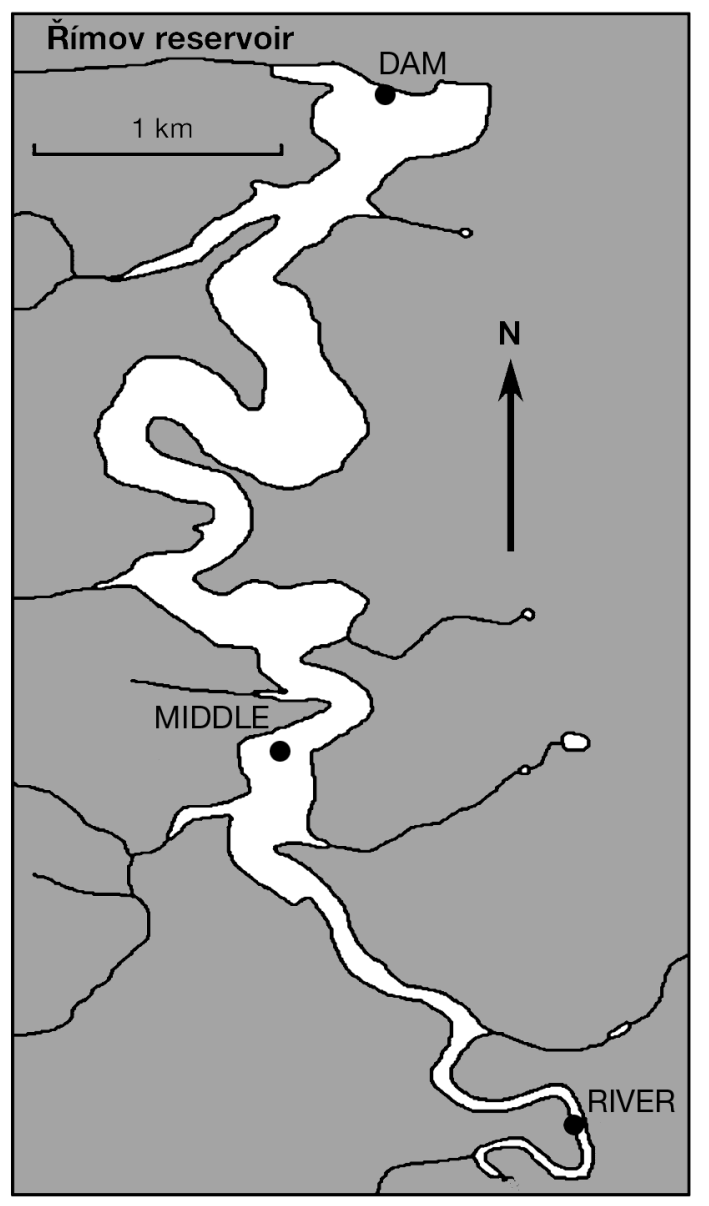

Fig. 1. The canyon-shaped Rímov reservoir with locations of the DAM, MIDDLE and RIVER sampling stations

and enumerated under epifluorescence microscopy (Olympus BX 60 or AX 70). Cell sizing was conducted using the semiautomatic image analysis systems LUCIA D (Lucia 3.52, Laboratory Imaging, Prague). Both approaches are detailed in Posch et al. (1997) and Šimek et al. (2001).

Bacterial production and carbon demand. BP was measured as incorporation of $\left[{ }^{3} \mathrm{H}\right]$-thymidine (ICN) using the method modified from Riemann \& Søndergaard (1986); for details, see Straškrabová et al. (1999). Triplicate $5 \mathrm{ml}$ subsamples were incubated in the dark and at in situ temperature for $60 \mathrm{~min}$ and filtered through polycarbonate filters (pore size $0.2 \mu \mathrm{m}$, OSMONIC). Blanks were fixed with $2 \%$ formaldehyde. Filters were then extracted 5 times with $2 \mathrm{ml}$ of $5 \%$ TCA. To estimate cell production rate (cells $\mathrm{d}^{-1}$ $\mathrm{ml}^{-1}$ ), the empirically established mean conversion fac-

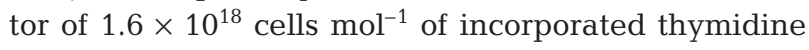
was applied based on 12 measurements of in situ bacterial cell number increase in $1 \mu \mathrm{m}$ filtrate incubated in a dialysis bag in situ (cf. Šimek et al. 2006). To obtain bacterial carbon demand (BCD), cell production rate was multiplied by average cell carbon content estimated from sizing of bacterial cells by image analysis (Posch et al. 1997) and corrected for growth efficiency, assumed to be $40 \%$.

Protozoan grazing and enumeration. Protozoan bacterivory was estimated using fluorescently labelled bacteria (FLB) concentrated from the reservoir water. Heterotrophic nanoflagellate (HNF) and ciliate abundances and FLB uptake rates were determined in short-term FLB direct-uptake experiments described in detail in Šimek et al. (2001). To estimate total protozoan grazing, we multiplied the average uptake rates of HNF and ciliates by their in situ abundance.

In situ hybridization with rRNA-targeted oligonucleotide probes. Analysis of bacterioplankton was performed only at the DAM site using group-specific rRNA-targeted oligonucleotide probes. We applied the catalyzed reporter deposition fluorescence in situ hybridization (CARD-FISH) protocol (Pernthaler et al. 2002) employing the following oligonucleotide probes (Thermo, Ulm, Germany) targeted to the domain Bacteria (EUB338), the Beta- and Gamma-subclasses of the class Proteobacteria (the BET42a and GAM42a probes, respectively), a subcluster of Betaproteobacteria (R-BT065, this probe targets a subcluster of the Rhodoferax sp. BAL47 cluster of Betaproteobacteria, Zwart et al. 2002), the whole Polynucleobacter cluster of Betaproteobacteria (PnecABCD-445, Hahn et al. 2005), the Cytophaga/Flavobacterium/Bacteroidetes group (CF319a) and the Actinobacteria group (HGC69a). The proportions of FISH-positive bacteria were detected directly by inspecting the samples via epifluorescence microscopy (Olympus AX-70).

Phytoplankton composition, biovolume and chlorophyll a determination. Phytoplankton samples for biovolume estimation were preserved with a Lugol's solution. Phytoplankton species were enumerated in the Utermöhl sedimentation chamber on an inverted microscope (Olympus IMT-2). The mean algal cell dimensions were obtained for biovolume calculation using the approximation of cell morphology to regular geometric shapes and converted to carbon biomass by using conversion factor of $200 \mu \mathrm{g} \mathrm{C} \mathrm{mm}{ }^{-3}$ (Straškrabová et al. 1999). Chlorophyll a (chl a) concentration was determined spectrophotometrically after the extraction with acetone (Lorenzen 1967).

Phytoplankton primary and extracellular production. Primary production and EPP rates were measured with the ${ }^{14} \mathrm{C}$-method as described in Straškrabová et al. (1999). Briefly, water samples were incubated in situ (2 light and 2 dark bottles at each station) at $0.5 \mathrm{~m}$ for $4 \mathrm{~h}$. Each bottle (volume $\sim 120 \mathrm{ml}$ ) received $\sim 0.2 \mathrm{MBq}$ of carrier-free ${ }^{14} \mathrm{C}$-bicarbonate (ICN; final chemical concentration $<10 \mu \mathrm{g} \mathrm{C}{ }^{-1}$ ). The assimilated ${ }^{14} \mathrm{C}$ was fractionated using a combination of the filtration and 
acidification methods. The activity in each size-fraction was expressed as a fraction of the added activity determined for each bottle separately in $1 \mathrm{ml}$ aliquots, multiplied by the dissolved inorganic carbon (DIC) concentration calculated from $\mathrm{pH}$ and the alkalinity determined by Gran titration, and corrected for dark-bottle values and the incubation time. To obtain per-day assimilation estimates, these per-hour carbon flux values $\left(\mu \mathrm{g} \mathrm{C} \mathrm{l}^{-1} \mathrm{~h}^{-1}\right)$ were multiplied by the length of daylight period (approximated as the interval between sunrise and sunset minus $2 \mathrm{~h}$ ). The organic ${ }^{14} \mathrm{C}$ passing the filter with porosity $1 \mu \mathrm{m}$ (Poretics, Osmonics) was considered to be equivalent to EPP, since no autotrophic picoplankton $<1 \mu \mathrm{m}$ was detected in the filtrate (P. Znachor unpubl. data). We used a low vacuum $(<0.1 \mathrm{~atm})$ for filtration to avoid cell disruption. The filtrate was acidified with $\mathrm{HCl} 0.01 \mathrm{~mol} \mathrm{l}^{-1}$ (final concentration) and air-bubbled for $1 \mathrm{~h}$ to remove inorganic carbon. The activity in $10 \mathrm{ml}$ portions of the filtrate was measured by scintillation spectrometry using a gelforming scintillation cocktail (Quicksafe A, Zinsser Analytics).

Zooplankton community composition. Zooplankton were collected and analyzed only at Stn DAM. The crustaceans were sampled by vertical hauls using an Apstein plankton net (net mesh $=200 \mu \mathrm{m}$ ). The hauls were taken from the depth of $4 \mathrm{~m}$ to the surface, which mostly represents the depth of epilimnion where usually $90 \%$ of the crustaceans from the whole water column are accumulated (Sed'a et al. 2007). The rotifers were sampled also from the uppermost $4 \mathrm{~m}$ of the water column using a plastic tube of the appropriate length. The sampled water of known volume (40 l) was subsequently filtered by $35 \mu \mathrm{m}$ net. The zooplankton samples were preserved in $4 \%$ formaldehyde and the abundance of the main zooplankton species were determined microscopically (McCauley 1984).

\section{Carbon and phosphorus concentra-}

tions. DOC was analyzed in samples filtered through glass-fiber filters of $0.4 \mu \mathrm{m}$ nominal pore size (GF-5, Macherey-Nagel) with a TOC 5000A analyzer (Shimadzu). Particulate organic carbon (POC) was analyzed on GF-5 filters by high-temperature ignition with a TOC/ SSM5000A analyzer (Shimadzu). Dissolved reactive phosphorus (DRP as $\mathrm{PO}_{4}-\mathrm{P}$ ) was analyzed according to Murphy \& Riley (1962). Total phosphorus (TP) was determined by the molybdate method following perchloric acid digestion according to Kopáček \& Hejzlar (1993). Particulate phosphorus (PP) was determined as the difference between the TP in the original samples and in the samples filtered through GF-5 filters. Molar $\mathrm{C}: \mathrm{P}$ ratio in sestonic particles was calculated from $\mathrm{POC}$ and PP concentrations.

Statistical analysis. One-way ANOVA with Bonferroni's multiple comparison test was applied to test for differences in chemical and biological parameters at Stns DAM, MIDDLE and RIVER over the whole study period. A 2-tailed $t$-test was used to test for differences in relative proportions of distinct subgroups of bacteria (targeted by 6 oligonucleotide group-specific FISH probes) in total bacterioplankton numbers over the periods when either cryptophytes or diatoms dominated the phytoplankton biomass at Stn DAM. A multiple linear regression with stepwise forward selection (Statistica, StatSoft) was made to relate the extracellular production rate of the phytoplankton to the biomass of 8 phytoplankton taxonomic groups distinguished at Stn DAM.

\section{RESULTS}

\section{Water chemistry and phytoplankton parameters}

Over the study period, water temperatures ranged from 7 to $23^{\circ} \mathrm{C}$ at the DAM and MIDDLE sites and from 4.5 to $18^{\circ} \mathrm{C}$ at the RIVER inflow. While DOC showed no clear trend along the longitudinal axis of the reservoir (cf. Fig. 1, Table 1), POC displayed a modest decreasing trend from RIVER downstream. However, these differences were not significant (ANOVA). In contrast, parameters of phosphorus (TP, PP and DRP, Table 1) showed a significant decreasing trend from RIVER to DAM (ANOVA, p < 0.005), reflected also in an increasing sestonic C:P molar ratio downstream of the reservoir. Primary production and chl a concentration showed the lowest means at RIVER, maxima in

Table 1. Basic chemical and phytoplankton bulk biomass and primary production data at the 3 stations. DOC, dissolved organic carbon; POC, particulate organic carbon; DRP, dissolved reactive phosphorus; TP, total phosphorus; $\mathrm{PP}$, particulate phosphorus; C:P, carbon to phosphorus ratio in seston; P prod., primary production. Different superscripted letters indicate a significant difference between stations ( $p<0.05$, ANOVA, followed by Bonferroni's multiple comparison test); ns: not significant

\begin{tabular}{|c|c|c|c|c|}
\hline Parameter & $\begin{array}{l}\text { Significance } \\
\text { o (ANOVA) }\end{array}$ & DAM & $\begin{array}{c}\text { MIDDLE } \\
\text { Mean (range) }\end{array}$ & RIVER \\
\hline $\mathrm{DOC}\left(\mathrm{mg} \mathrm{l}^{-1}\right)$ & $\mathrm{ns}$ & $6.1(4.9-7.7)$ & $6.3(4.6-10)$ & $6.6(3.6-8.8)$ \\
\hline $\mathrm{POC}\left(\mathrm{mg} \mathrm{l}^{-1}\right)$ & ns & $0.8(0.2-1.6)$ & $1.0(0.3-1.9)$ & $1.6(0.3-5.5)$ \\
\hline $\operatorname{DRP}\left(\mu g \mathrm{l}^{-1}\right)$ & $<0.0001$ & $8(2-27)^{\mathrm{a}}$ & $11(5-24)^{\mathrm{a}}$ & $24(8-44)^{\mathrm{b}}$ \\
\hline $\mathrm{TP}\left(\mu \mathrm{g} \mathrm{l}^{-1}\right)$ & $<0.003$ & $29(17-57)^{a}$ & $44(23-79)^{\mathrm{a}, \mathrm{b}}$ & $70(25-140)^{b}$ \\
\hline $\mathrm{PP}\left(\mu g \mathrm{l}^{-1}\right)$ & $<0.005$ & $13(5-23)^{a}$ & $21(7-41)^{a}$ & $33(7-108)^{b}$ \\
\hline $\mathrm{C}: \mathrm{P}$ ratio (molar) & ns & $162(67-301)$ & $122(66-205)$ & $107(72-131)$ \\
\hline $\operatorname{chl} a\left(\mu g l^{-1}\right)$ & ns & $8(1-25)$ & $10(2-30)$ & $3(1-6)$ \\
\hline P prod. $\left(\mu \mathrm{g} \mathrm{C} \mathrm{l}^{-1} \mathrm{~d}^{-1}\right)$ & 1) $\mathrm{ns}$ & $460(17-1528)$ & $880(12-4296)$ & $157(7-424)$ \\
\hline
\end{tabular}


MIDDLE and slightly lower levels at DAM (Table 1). However, these differences were insignificant (ANOVA). The proportion of BP in total primary production was seasonally highly variable, averaging 3.6, 3.1 and $25 \%$ at the DAM, MIDDLE and RIVER stations, respectively.

\section{Time-course changes in microbial abundance and biomass}

At each sampling station, trends in bacterial abundance and biomass tightly coincided (Fig. 2), since no large changes in mean cell volume of bacteria were detected (data not shown). While bacterial abundance at DAM and MIDDLE ranged similarly, between $1 \times 10^{6}$ and $5 \times 10^{6}$ cells ml $^{-1}$, the RIVER station showed generally larger seasonal fluctuations (Fig. 2). Overall, however, no significant differences in average bacterial abundance and biomass were found between the study sites (ANOVA). In contrast, protistan abundance and bacterivory, chl a concentration and primary production (Figs. 2 to 4, Table 1) showed larger differences when the lacustrine DAM and MIDDLE sites were compared to the RIVER station. Thus, average HNF and ciliate abundances were similar at DAM and MIDDLE $\left(1.62 \times 10^{3}\right.$ and

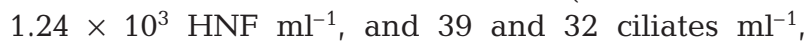
respectively), while HNF were significantly more abundant at DAM and MIDDLE (ANOVA, p < 0.05) than at the RIVER site $\left(0.31 \times 10^{3} \mathrm{HNF} \mathrm{ml}^{-1}\right.$ and 10 ciliates $\mathrm{ml}^{-1}$ ). These protistan groups showed marked spring and summer maxima at DAM and MIDDLE that were mostly reflected in their enhanced role as pelagic bacterivores (cf. Figs. $2 \& 3$ ).

\section{Top-down factors controlling bacterioplankton community dynamics}

At all 3 reservoir sites, BP showed a spring peak in late May and a summer peak on 23 August at DAM and MIDDLE, but due to a severe flood event BP and protistan bacterivory could not be detected at the RIVER site on this date (Fig. 3). A clear trend of an increasing role of protistan grazing in controlling BP was detected from RIVER downstream to lacustrine parts of the reservoir, with average values of 9,47 and $78 \%$ of BP grazed at RIVER, MIDDLE and DAM, respectively. Protistan grazing was dominated by HNF (on average 56 and $58 \%$ of total protistan bacterivory at DAM and MIDDLE, respectively) over ciliate grazing. However, we found remarkable temporal oscillations in the roles of HNF and ciliates as bacterivores (Fig. 3). For instance, concomitantly with the ciliate abundance peaks (cf. Fig. 3), they became the dominant protistan bacterivores in April and August at DAM and in May at MIDDLE when small fine-suspension feeding choreotrichous ciliates prevailed in the ciliate community (data not shown). In contrast, during the chl a minimum during the zooplankton-induced spring clear water phase (Fig. 4; DAM: May 31,

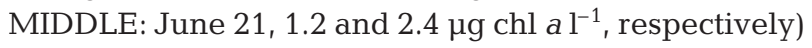
HNF and ciliate abundances dropped substantially (Fig. 2) and consequently total protozoan grazing controlled less than $10 \%$ of BP.

Only at the DAM site were changes in zooplankton and phytoplankton composition detected (Figs. 5 \& 6). Rotifers showed 2 seasonal maxima at DAM (May and August) approximately corresponding with the maxima in phytoplankton biomass and chl a concentration (cf. Figs. 4 to 6). Cladocera increased dramatically from March to the late May-June period $\left(\sim 200\right.$ ind. $\left.\mathrm{l}^{-1}\right)$, with the community dominated mainly by Daphnia galeata and less by the genera Bosmina and Eubosmina. Highest abundance of D. galeata coincided with the highest water transparency (DAM on May 31) and coincided with decreased bacterioplankton abundance and biomass. This point also represented the lowest HNF and ciliate abundances and thus also their bacterivory, as well as very low phytoplankton biomass and low abundance of rotifers (cf. Figs. 2 to 6). After July 12, a marked shift in Cladocera community composition occurred towards increasing proportions of Diaphanosoma brachyurum and Ceriodaphnia quadrangula. From late August the latter species completely dominated the community while protozoan and bacterial abundances displayed mostly a decreasing trend during the autumn period (cf. Figs. $2 \& 5$ ).

A phylogenetic analysis of bacterioplankton community composition at the DAM site (Fig. 6, Table 2) did not show obvious relationships with top-down factors potentially controlling bacterioplankton dynamics. Thus, neither absolute numbers nor the relative proportions of any of the FISH-targeted bacterial groups in total bacterioplankton showed significant correlations to abundance of zooplankton, HNF, ciliates or to their aggregated bacterivory (cf. Figs. 6 \& 2, 3 \& 5), or to the proportion of BP removed by protists per day (data not shown).

\section{Relating phytoplankton dynamics and production to bacterioplankton dynamics}

At the DAM site, chl a concentrations showed the spring maximum in mid-April, a dramatic drop in late May and 2 summer maxima in the July-August period (Fig. 4). The first maximum was related to the very 

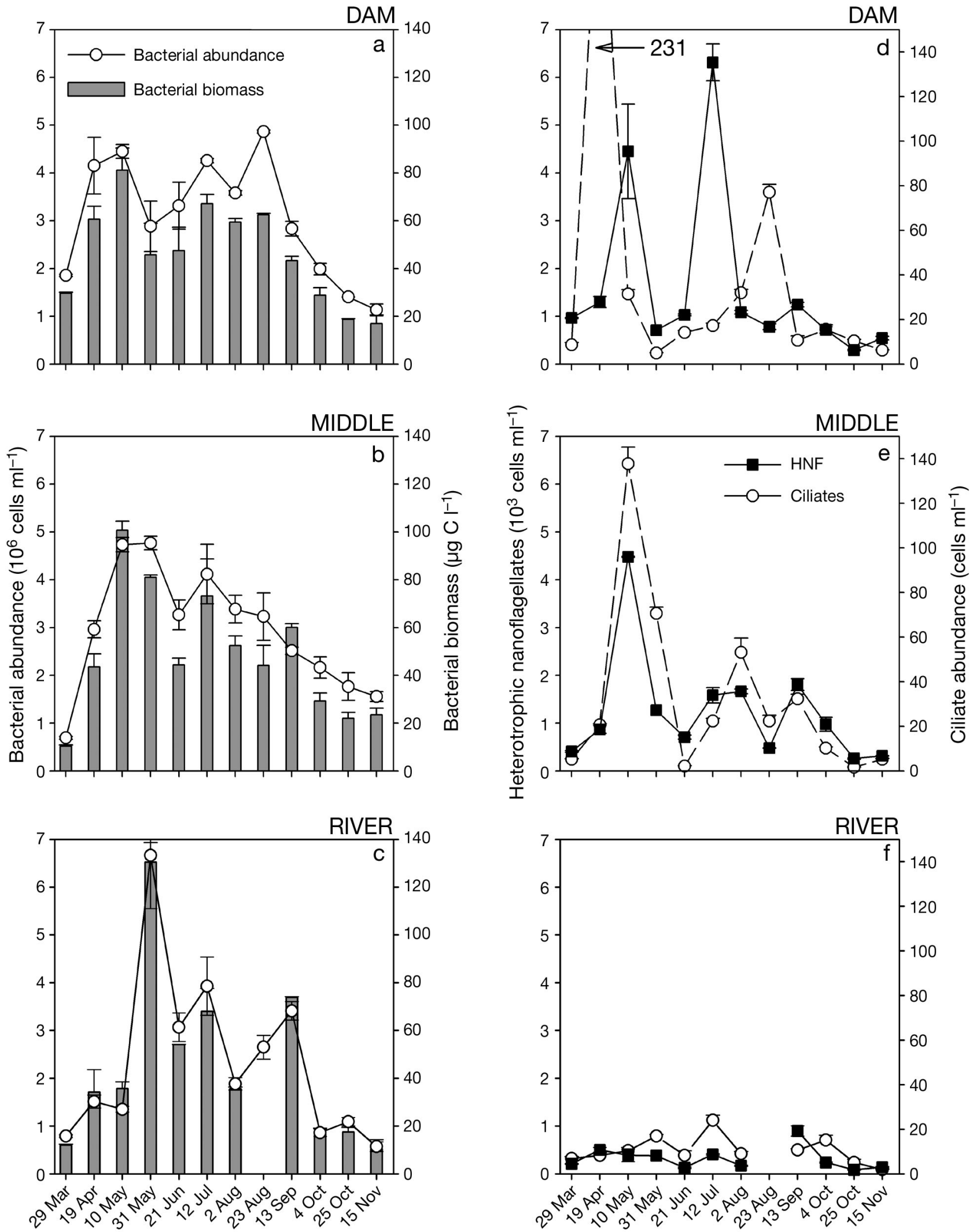

Fig. 2. Time-course changes in $(\mathrm{a}-\mathrm{c})$ bacterial abundance and biomass and $(\mathrm{d}-\mathrm{f})$ abundance of heterotrophic nanoflagellates (HNF) and ciliates at each of the 3 stations. Values are means of duplicate treatments; vertical bars show ranges 

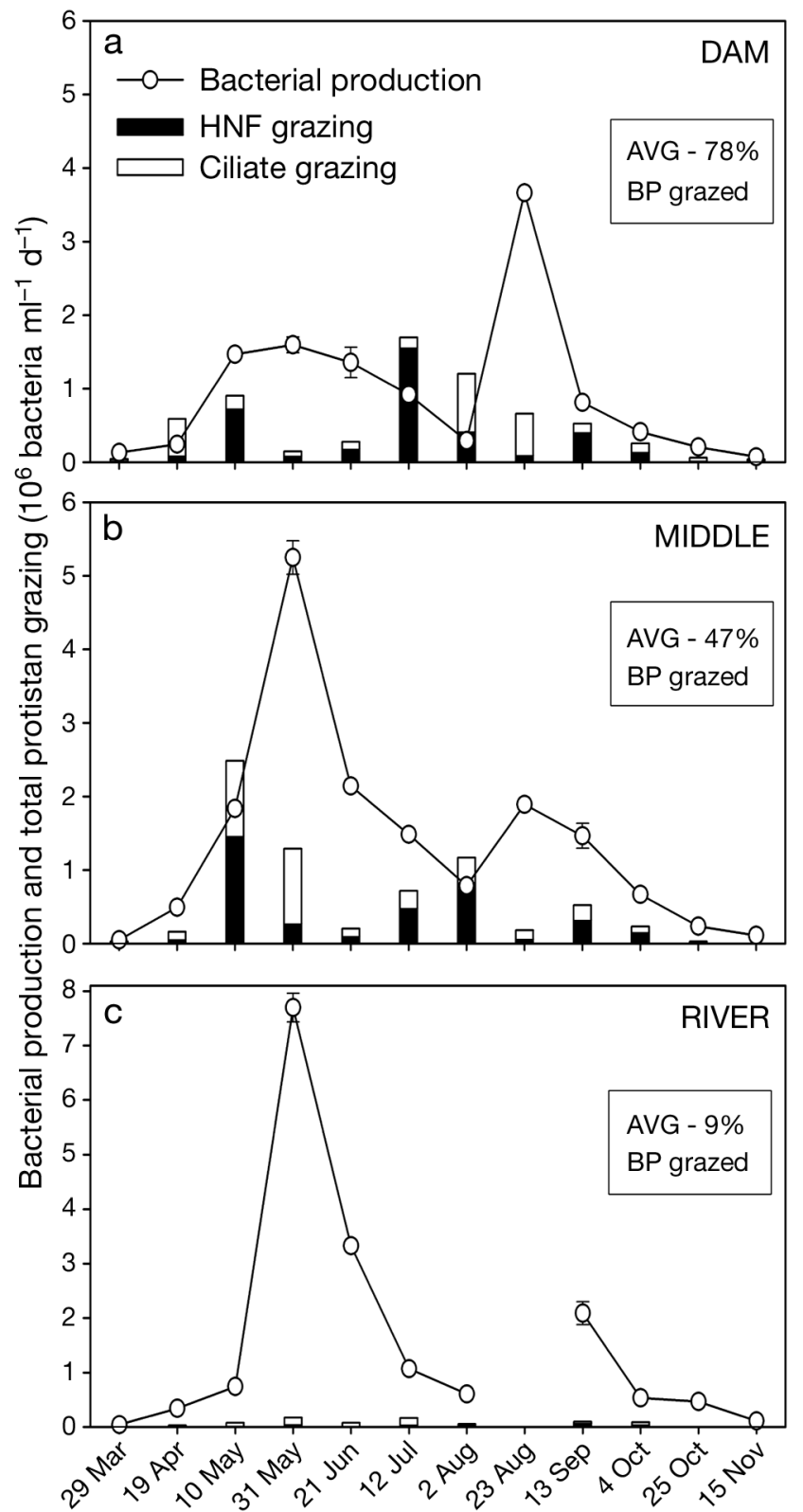

Fig. 3. Time-course changes in bacterial production (BP) and total protistan bacterivory divided into heterotrophic nanoflagellate (HNF) and ciliate grazing at the (a) DAM, (b) MIDDLE and (c) RIVER stations. Next to each panel, an average (AVG) proportion of BP grazed by the total protozoa over the study period is shown. Values for BP are means of duplicate treatments; vertical bars show ranges

high biomass of colonial diatoms (July, Fig. 6), while the second summer maximum, predominated by cryptophytes, developed as a response to a sudden pulse of nutrient-rich river waters into the reservoir epilimnion induced by a flood event in the middle of August. Changes in EPP were compared to BCD. There were important differences between the lacustrine and inflow areas of the reservoir: At the RIVER

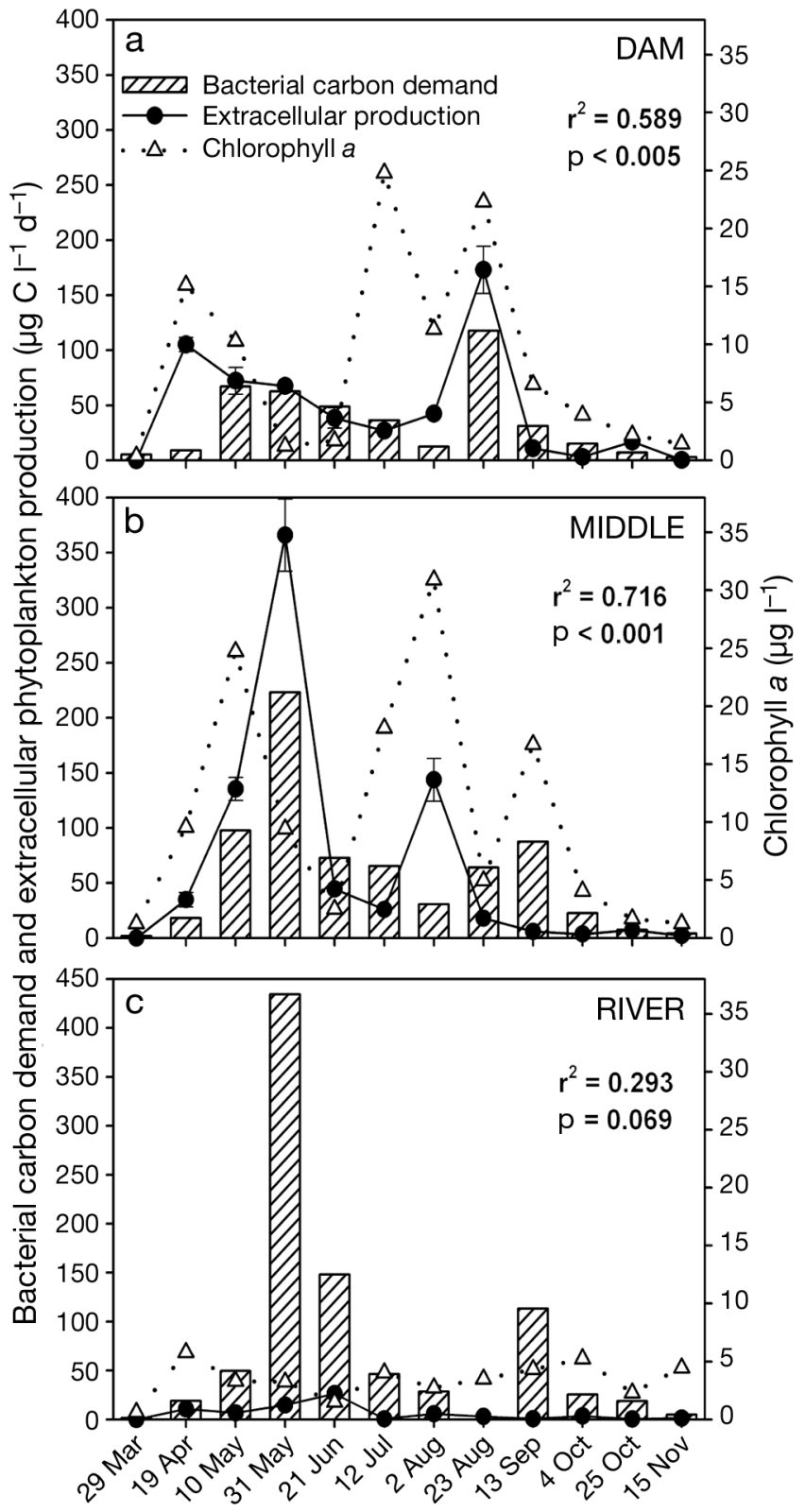

Fig. 4. Time-course changes in chl a concentration and extracellular phytoplankton production compared to bacterial carbon demand estimated from carbon cell production rate at the (a) DAM, (b) MIDDLE and (c) RIVER stations (for more details see 'Materials and methods'). Values for bacterial carbon demand are means of duplicate treatments; vertical bars show ranges. $\mathrm{r}^{2}$, coefficient of determination of the regressions between extracellular phytoplankton production and bacterial carbon demand $(\mathrm{n}=12)$

site, on average only $24 \%$ of BCD could be met by EPP and, moreover, the 2 parameters were not significantly correlated (Fig. 4). In contrast, at the MIDDLE and DAM sites, EPP represented on average 133 and $204 \%$ of $\mathrm{BCD}$, respectively. Moreover, seasonal trends of these parameters were significantly correlated (see Fig. 4). However, during the summer-autumn period 

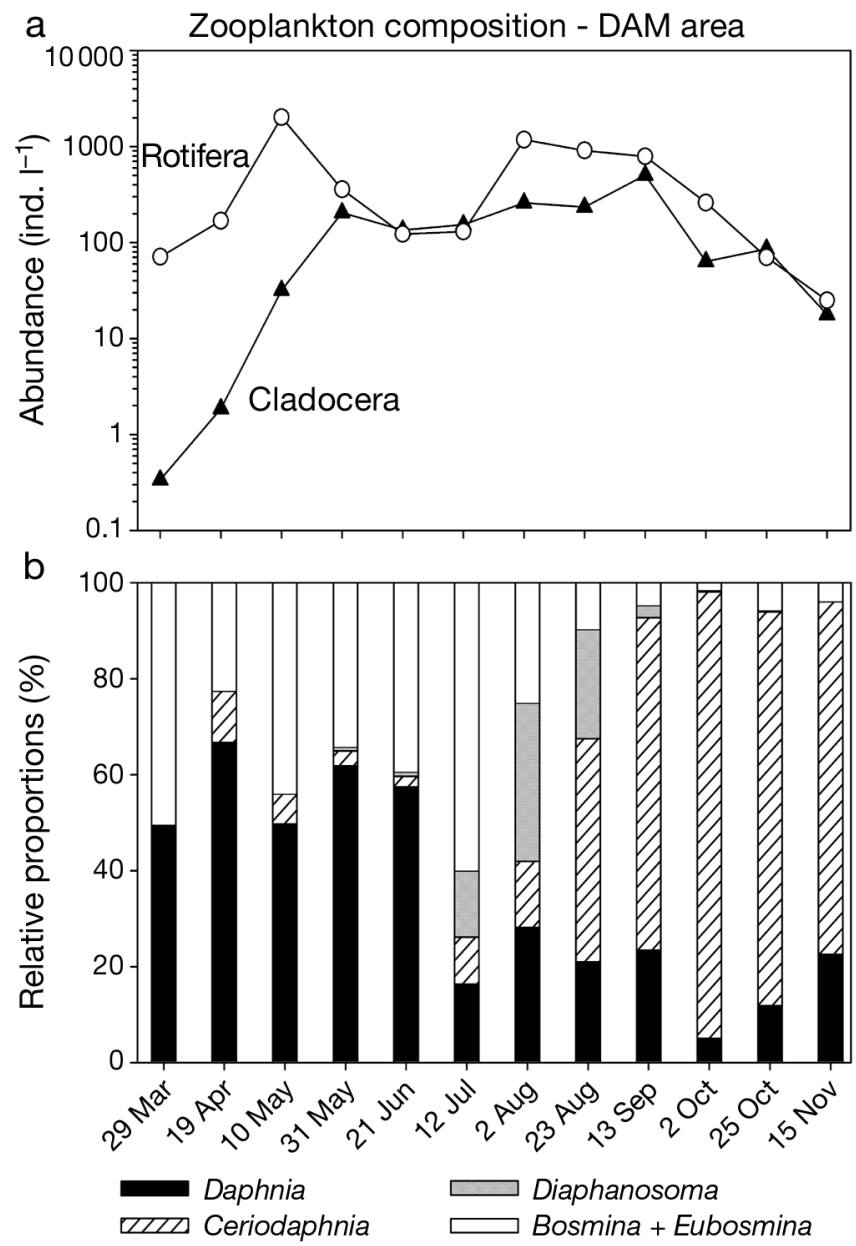

Fig. 5. Time-course changes at the DAM station in (a) abundance of rotifers and cladocerans and (b) relative proportions of different genera of Cladocera to total Cladocera. Only filter feeding cladocerans and rotifers are evaluated, i.e. the predatory cladoceran Leptodora kindti and the predatory rotifer Asplanchna sp. were not included in the data set

of diatom dominance at the DAM site, we estimated relatively low EPP, often insufficient to meet BCD (Figs. 4 \& 6).

Only 2 groups, cryptophytes, in the spring-early summer, and diatoms, in the summer-fall period, alternatively dominated the community at the DAM site (Fig. 6). The pooled biomass of the latter 2 groups always accounted for $>65 \%$ of total phytoplankton biomass, while a pooled biomass of the other 6 phytoplankton groups designated as 'others' in Fig. 6, i.e. chlorophytes, dinophytes, chrysophytes, cyanobacteria, euglenophytes and desmids, always accounted for $<35 \%$. Overall, EPP showed a significant but loose correlation with the bulk phytoplankton biomass $\left(\mathrm{r}^{2}=0.347, \mathrm{p}=0.044\right)$. The taxon-specific effect of each of the individual phytoplankton groups on EPP was tested separately using a multiple
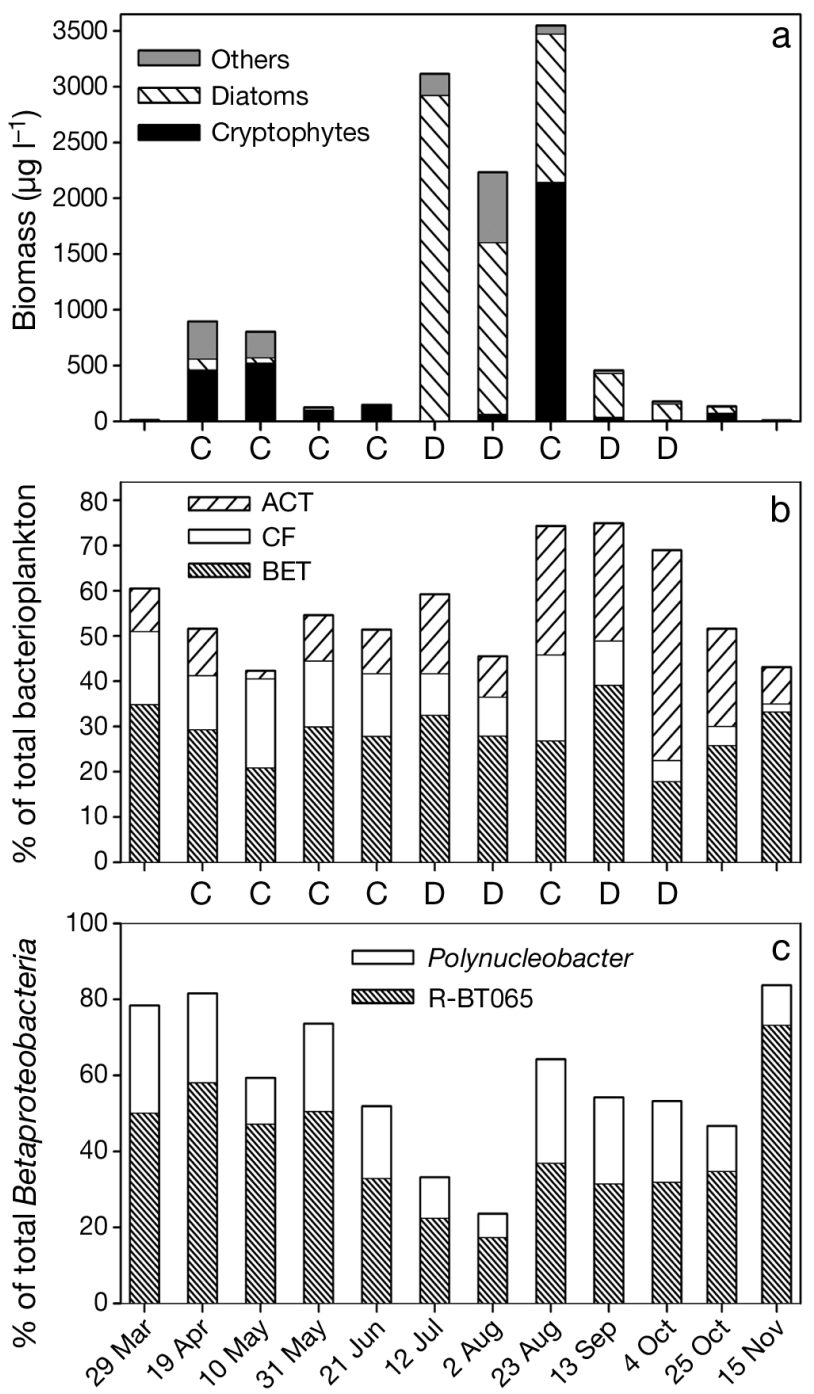

Fig. 6. Time-course changes at the DAM station in (a) phytoplankton community composition expressed as carbon biomass of its dominant groups (for more details see 'Materials and methods'), (b) relative proportions (\%) of Betaproteobacteria (BET), Cytophaga/Flavobacterium/Bacteroidetes (CF) and Actinobacteria (ACT) groups to total DAPI-stained bacterioplankton numbers and (c) relative proportions (\%) of the R-BT065 and Polynucleobacter subclusters of Betaproteobacteria to total Betaproteobacteria numbers considered as $100 \%$. 'C' and 'D' labels indicate the sampling dates with cryptophyte or diatom dominance $(>60 \%)$, respectively, in total phytoplankton biomass

regression analysis with stepwise forward selection. Only cryptophytes had a significant association with EPP. Subsequent analysis revealed that this relationship was best fitted with a logarithmic function (Fig. 7). Moreover, the proportion of EPP in total phytoplankton production was significantly higher ( $\mathrm{p}<0.001$ ) during the periods dominated by cryptophytes compared to diatom-dominated periods (17.9 versus $4.6 \%$ ). 
Table 2. At the DAM station, mean (range) of relative proportions (\%) of different subgroups of bacteria to total bacterioplankton targeted with the 6 oligonucleotide probes (for details see 'Materials and methods') over periods when cryptomonads or diatoms accounted for $>60 \%$ of total phytoplankton biomass. Significant differences by a 2 -tailed $t$-test are shown in bold. ${ }^{*} \mathrm{p}<0.05 ;{ }^{* *} \mathrm{p}<0.01$

\begin{tabular}{|c|c|c|c|}
\hline \multirow[t]{2}{*}{ Bacterial group } & \multicolumn{2}{|c|}{ Mean percentage of total bacteria (range) } & \multirow[t]{2}{*}{$\mathrm{p}$} \\
\hline & $\begin{array}{l}\text { eriod of dominance } \\
\text { cryptomonads }(n=5)\end{array}$ & $\begin{array}{l}\text { Period of dominance } \\
\text { of diatoms }(\mathrm{n}=4)\end{array}$ & \\
\hline Eubacteria & $72(56-86)$ & $79(65-86)$ & 0.351 \\
\hline Betaproteobacteria & $27(21-30)$ & $29(18-39)$ & 0.642 \\
\hline R-BT065 cluster & $12(8.9-17)$ & $7.7(4.9-11)$ & $0.044^{*}$ \\
\hline Polynucleobacter cluster & $5.8(2.5-6.9)$ & $4.4(1.7-8.8)$ & 0.478 \\
\hline Cytophaga/Flavobacterium/Bacteroidetes group & $16(12-20)$ & $8.1(4.7-9.8)$ & $0.005^{* *}$ \\
\hline Actinobacteria group & $12(2-28)$ & $25(9-46)$ & 0.226 \\
\hline Sum of the R-BT065 and Polynucleobacter clusters in total Betaproteobacteria & $65(54-82)$ & $41(24-54)$ & $0.041^{*}$ \\
\hline
\end{tabular}
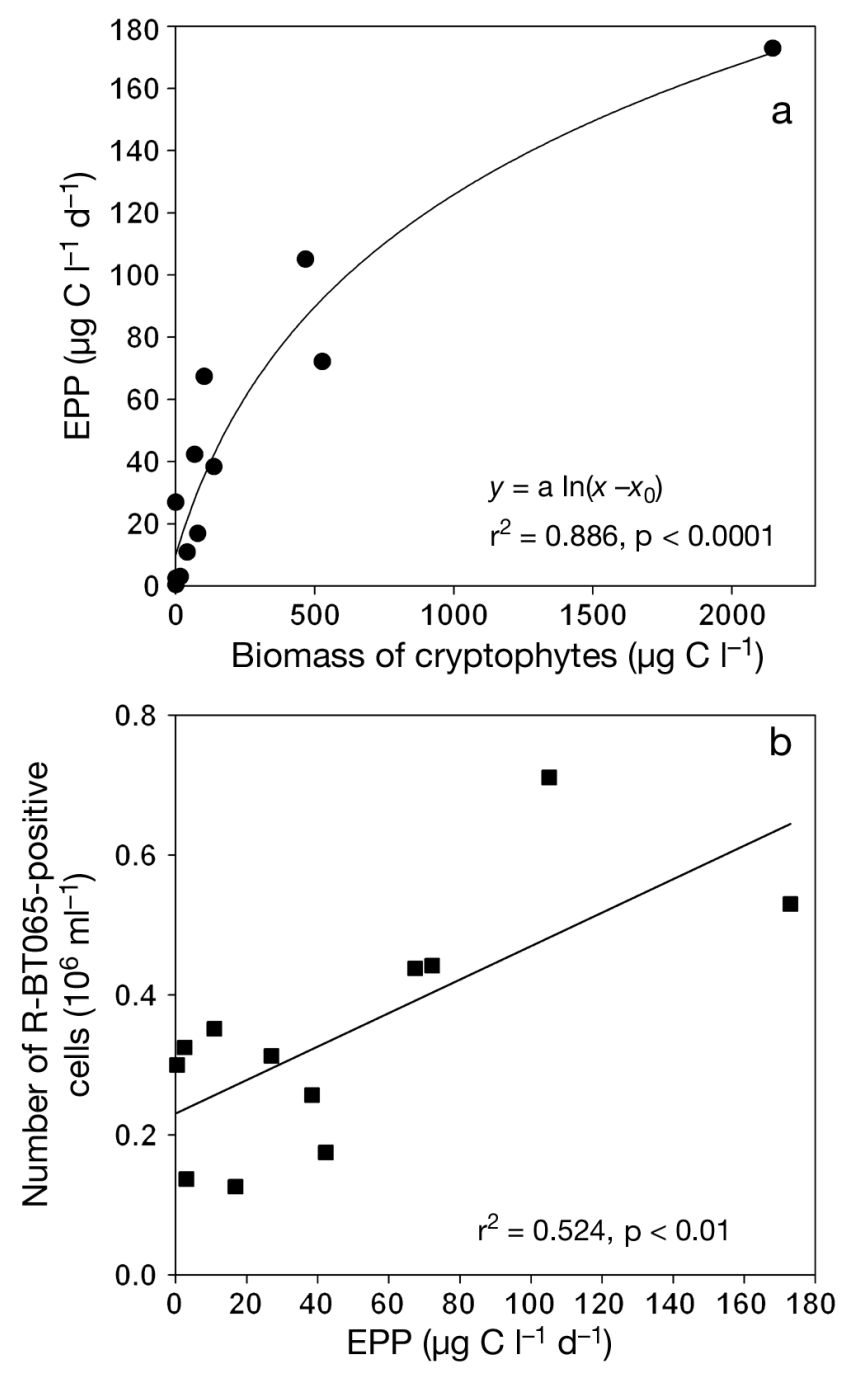

Fig. 7. At the DAM station: (a) relationship of extracellular phytoplankton production (EPP) to the carbon biomass of cryptophytes fitted with a logarithmic function and (b) relationship of numbers of bacteria hybridized with the R-BT065 probe (targeting a subcluster of Betaproteobacteria) with EPP fitted by linear regression. $\mathrm{r}^{2}$ is the coefficient of determination of the regressions between the 2 parameters $(n=12)$
The occurrence of contrasting situations of either cryptophyte or diatom dominance allowed us to examine the effect of changes in phytoplankton composition on bacterioplankton community composition. Nine out of 12 sampling data points could be sorted according to the clear dominance of either group ( $>60 \%$ of total biomass). The following samples did not meet the above criterion and thus were omitted from the analysis: October 25, practically equal biomass of both groups, and March 29 and November 15, an overall negligible total phytoplankton biomass (Fig. 6) and, moreover, low proportions of these 2 groups.

This data treatment yielded sets of 5 and 4 data points with the dominance of cryptophytes and diatoms, respectively (Fig. 6). Differences in relative proportions of various phylogenetic bacterial groups in total bacterioplankton were tested (cf. Fig. 6, Table 2). No significant differences were found for proportions of the domain Bacteria and the whole group of Betaproteobacteria. However, the R-BT065 subcluster of Betaproteobacteria, Cytophaga/Flavobacterium/Bacteroidetes group, and a sum of proportions of the R-BT065 and Polynucleobacter clusters in total Betaproteobacteria (Fig. 6) contributed significantly more to total bacterioplankton during the periods dominated by cryptophytes. In contrast, the relative abundance of the Actinobacteria group doubled during diatom-dominated periods; however, due to the large scatter of the data (Fig. 6) this apparent pattern was not statistically significant. Only the abundance of bacterial populations hybridized with the R-BT065 probe (the cluster of Betaproteobacteria, Fig. 7a) was significantly correlated with the bulk EPP.

\section{DISCUSSION}

\section{Spatio-temporal trends in top-down control of bacterioplankton dynamics}

Protistan grazing pressure was insufficient to control BP at the RIVER station (Fig. 3), as found in a previous 
study (Jezbera et al. 2003). Moreover, densities of rotifers and cladocerans, i.e. zooplankton groups capable of cropping a broad spectrum of microbial organisms (Jürgens 1994), are consistently negligible at the RIVER station (Sed'a et al. 2007, J. Sed'a unpubl. data).

Interestingly, a manipulation experiment conducted earlier at the DAM and RIVER sites (Weinbauer et al. 2003) showed that the contribution of virus-induced mortality to the total bacterial loss rate was much greater (around $50 \%$ of BP) in the resource-rich RIVER site. It indicated that viruses might have stronger impacts on shaping bacterial community dynamics in a resource-rich (mainly phosphorus-rich) environment, while grazing played a more important role in the more resource-limited lacustrine reservoir parts (cf. our Table 1 and Šimek et al. 2005), a common trend that was also documented in the present study (cf. Fig. 3).

A detailed analysis of trends in biological parameters in 6 longitudinal transects conducted in 1999 showed that the parts of the Rímov reservoir downstream from the river plunge-point to MIDDLE is the most productive area in terms of primary production and BP (for details see Jezbera et al. 2003, Mašín et al. 2003). This finding was also obvious in the present seasonal study (cf. Table 1, Figs. 2 to 4). However, abundances of HNF and ciliate frequently peaked at DAM irrespective of enhanced levels of BP at Stn MIDDLE (cf. Jezbera et al. 2003). This phenomenon is probably a consequence of the generally higher densities of zooplankton found at the MIDDLE site (Sed'a et al. 2007) since larger zooplankton are known to exert strong top-down control on members of microbial food webs (Pace et al. 1990, Jürgens 1994). The enhanced grazing impact of cladocerans on protistan populations was most obvious during the clear-water phase (May to early June) when HNF and ciliate abundances and bacterivory dropped substantially (Figs. 2 \& 3). Grazing of abundant cladoceran populations likely also controlled most of the BP at the DAM and MIDDLE stations during the clearwater phase and early August when only a small part of bacterial mortality could be attributed to protozoan grazing (cf. Figs. 3 \& 5).

Zooplankton composition at DAM seemed to be affected by a marked shift in phytoplankton composition from cryptophytes, easily exploited by zooplankton (Richman \& Dodson 1983), to the dominance of inedible large colonies of a diatom Fragilaria crotonensis (Znachor \& Nedoma 2008). This phytoplankton compositional shift was paralleled by a marked shift towards dominance of the fine-mesh cladoceran filter feeders Diaphanosoma brachyurum, followed by Ceriodaphnia quadrangula (Fig. 5), considered to be highefficiency bacterial feeders (Geller \& Müller 1981). During the August to October period, the bacterivory of these species probably contributed to the control of $\mathrm{BP}$, since protistan grazing mostly controlled $<50 \%$ of $\mathrm{BP}$ at the DAM and MIDDLE sites.

Surprisingly, using a regression analysis, we did not detect any marked association between seasonal changes in any of the zooplankton or protistan bacterivorous groups and basic chemical parameters, or between bacterioplankton community composition and mortality rate. This partly contrasted with the conclusions drawn from previous short-term incubation studies, in which protistan grazing induced remarkable compositional shifts in bacterioplankton (see e.g. Šimek et al. 2001, Jezbera et al. 2005, Horňák et al. 2006). This inconsistency is likely related to the different sampling strategy applied in the present study (3 wk intervals), which does not reflect the typical doubling times of 1 to $2 \mathrm{~d}$ detected for the reservoir bacteria (Horňák et al. 2006, Šimek et al. 2006).

\section{Spatio-temporal trends in bottom-up control of bacterioplankton dynamics}

While overall comparable levels of bacterial biomass, BP, DOC and POC were estimated for all 3 study sites (cf. Table 1, Figs. 2 \& 3), distinctly different sources of organic carbon supported bacterial growth at the sites. In the upper, inflow part of the reservoir with limited phytoplankton development (our Table 1, Fig. 4; cf. also Mašín et al. 2003), the allochthonous organic matter from the river was likely the main carbon source fuelling $\mathrm{BP}$, since EPP amounted to only $24 \%$ of BCD there (Fig. 4). The less important role of EPP in carbon dynamics of running waters seems to be a common feature. For instance, Descy et al. (2002) estimated that EPP covers on average only $22 \%$ of $\mathrm{BCD}$ in the eutrophic River Meuse system. In contrast, in a study comparing general patterns across typical pelagic freshwater and marine systems it was estimated that EPP usually amounts to about $50 \%$ of BCD (Baines \& Pace 1991). Thus, in contrast to the RIVER site, EPP was a largely sufficient source of organic carbon to meet BCD at the lacustrine MIDDLE and DAM sites, and the parameters were very tightly correlated. This points to the important role of autochthonously produced organic carbon in regulating BP in the lacustrine reservoir parts, as has been reported for a variety of pelagic systems (Larsson \& Hagström 1982, Baines \& Pace 1991).

In the lacustrine reservoir sites, in only a few cases were EPP levels insufficient to meet BCD (Fig. 4), e.g. at the DAM site during the late summer-fall period when diatoms dominated the phytoplankton (cf. Fig. 6). However, during this period, decaying phytoplankton biomass may represent an important carbon pool for bac- 
teria (e.g. Simon et al. 2002) and significant amounts of DOC can be released through the processes of sloppy feeding and excretion by zooplankton that supplies a high-quality substrate pool for bacteria (e.g. Hygum et al. 1997). Thus, feeding activity of highly abundant macro- and micro-zooplankton (see e.g. the period August to October at DAM, Fig. 5) was likely an important source of organic carbon fuelling BP.

Notably, the downstream decreasing availability of phosphorus (Table 1) was paralleled by an increasing trend in EPP. In terms of seasonal averages, EPP accounted for $3.8,8.2$ and $10.3 \%$ of total primary production at the RIVER, MIDDLE and DAM stations, respectively. This fits a general assumption that nutrient-depleted phytoplankton increases organic carbon excretion rates (Lancelot 1983) and such a nutrient depletion is more likely to be met in the DAM area (Nedoma et al. 1993). Besides, we are aware of possible bias related to the use of $40 \%$ growth efficiency applied to estimate BCD in all stations as it usually holds for bacteria growing on easily utilizable substrates, such as algal exudates. The quality of organic substrates was likely different at the allochthonously loaded RIVER station richer in more refractory humic substances compared to the lacustrine parts of the reservoir where EPP seemed to be the dominant source of organic carbon to meet BCD of bacterioplankton assemblages (Fig. 4). However, the possible bias in using the fixed-growth efficiency factor could not explain the remarkable differences in balance between BCD and EPP at the RIVER station compared to the lacustrine parts of the reservoir.

\section{Phytoplankton composition and EPP levels}

The composition of EPP has been examined in both laboratory and field studies (e.g. Sundh 1992, Giroldo et al. 2007). However, we have rather limited knowledge of which groups of phytoplankton (and under which circumstances) are the major EPP producers. To our knowledge, this is the first study reporting an algal group of cryptophytes (dominated by Cryptomonas reflexa, C. marssonni and Rhodomonas minuta, P. Znachor unpubl. data) that are associated with high levels of EPP under natural conditions.

Notably, the ability of representatives of cryptophytes to release a significant proportion of primary production as EPP has been also frequently exploited in chemostat studies where exudation of e.g. Cryptomonas sp., growing in a phosphorus-limited inorganic medium, served as a sole source of organic carbon for growth of accompanying bacteria with a doubling time of 1 to 2 d (e.g. Šimek et al. 1997, Posch et al. 2001). Since the latter growth rates are quite comparable to those measured for bacterioplankton growing in situ on natural substrates present in the reservoir water (Šimek et al. 2006), the exudates of cryptophytes likely represent a rich substrate pool for bacteria. However, yet another question remains: Why does EPP increase nonlinearly, following a logarithmic function, with the biomass of cryptophytes (Fig. 7)? Even when 1 exceptionally high value of the cryptophyte biomass was re-

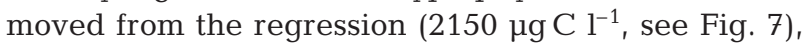
the data still fitted the same logarithmic function with only a slightly lower coefficient of determination of the regressions between the 2 parameters $\left(r^{2}=0.743, p<\right.$ $0001, \mathrm{n}=11$ ). One possibility explaining this relationship is the fact that high phytoplankton biomass is more likely to be nutrient limited, and thus becomes less productive per unit of biomass (Senft 1978). Notably, the trends in our data (cf. Figs. 4 \& 6) indicate that the diatom species dominant in the reservoir (Fragilaria crotonensis and Asterionella formosa) were, at least on a per unit of biomass basis, less important EPP producers than cryptophytes. Although we cannot fully exclude a certain EPP overestimation in cryptophytes due to cell breakage during filtration, it is unlikely that this artifact was responsible for observed large differences in EPP between the 2 phytoplankton groups. First, the vacuum used for filtration of samples was moderate $(<0.1 \mathrm{~atm})$, i.e. much lower than the 0.2 atm generally recommended to avoid cell rupture. Second, size-fractionation of EPP revealed that a considerable portion of EPP (on average $37 \%$ for cryptophytes-dominated samples and $31 \%$ for diatom-dominated ones, data not shown) was recovered in the bacterial fraction $(0.2$ to $1 \mu \mathrm{m})$ indicating the use of freshly released EPP by bacteria that had already occurred during incubation, i.e. prior to filtration.

\section{Impact of phytoplankton on bacterioplankton community composition}

There is growing evidence that phytoplankton composition has a significant impact on the composition of bacterioplankton communities (e.g. Lindström 2001, Grossart et al. 2005, Murray et al. 2007). In a study of 5 mesotrophic lakes in Sweden, bacterioplankton composition was found to be significantly related to the biomass of cryptophytes and diatoms; however, the mechanisms of such algal-bacterial interactions remained unexplained (Lindström 2000, 2001). Our study indicated that the mechanism of the specific algal-bacterial interactions and the key factor involved in shaping bacterial community (Fig. 6) could be the quantity and undoubtedly also the quality of EPP. Bacterial communities can specifically react to changes in the quality of utilizable compounds re- 
leased as EPP, and thus e.g. different species of marine diatoms harbor distinct bacterial communities (Grossart et al. 2005, Murray et al. 2007).

Only 2 phytoplankton groups overwhelmingly dominated the phytoplankton community (Fig. 6). Changes in the relative importance of the 2 groups coincided with interesting changes in the community composition of bacterioplankton. Notably, Betaproteobacteria and its R-BT065 and Polynucleobacter clusters and the Cytophaga/Flavobacterium/Bacteroidetes group (Fig. 6) accounted for significantly larger proportions of bacterioplankton during periods dominated by cryptophytes. However, only the probes targeting the genus-like RBT065 and Polynucleobacter clusters of Betaproteobacteria have a relatively fine taxonomic resolution (for the phylogenetic affiliations, see Šimek et al. 2001 and Hahn 2003, respectively). Both betaproteobacterial groups seem to utilize DOC derived from algal primary production (Burkert et al. 2003, Pérez \& Sommaruga 2006, Wu \& Hahn 2006) and, moreover, they are distributed worldwide (Zwart et al. 2002, 2003).

The members of the R-BT065 cluster are fastgrowing cells, vulnerable to protist predation, but with the ability to quickly respond to various manipulations in short-time dialysis bag incubation experiments (e.g. Šimek et al. 2001, 2005, Horňák et al. 2006). They have been identified as true opportunistic strategists among the reservoir bacterioplankton (Šimek et al. 2005, 2006), but we have not yet identified the major bottomup factors affecting their population dynamics. In the present study, we found that $>52 \%$ of the seasonal variability in the abundance of the members of the RBT065 cluster can be explained by changing EPP levels that were closely associated with the dynamics of cryptophytes. In addition, the R-BT065 cluster was the most prominent group in leucine uptake $(>90 \%$ of active cells detected via microautoradiography) and displayed an increased glucose-uptake activity during the spring cryptophyte bloom compared to the diatomdominated periods (K. Horňák unpubl. data). To our knowledge this is, in terms of taxonomic resolution of the major bacterial and algal players, a novel aspect of their community ecology not previously reported for freshwater plankton communities.

Other FISH probes used in the present study gave only a crude taxonomic resolution. Moreover, the broad bacterioplankton groups distinguished, such as Cytophaga/Flavobacterium/Bacteroidetes and Actinobacteria, represent large and metabolically very diverse groups (e.g. Kirchman 2002, Hahn \& Pöckl 2005). Even so, our finding that the phytoplankton community dynamics can differently affect their relative proportions and activity brings interesting insights. For instance, Actinobacteria were more represented in bacterioplankton during periods of diatom dominance. Additionally, data from microautoradiography showed increased proportions of cells active in leucine uptake (K. Horňák unpubl. data), which might indicate that diatoms provide a specific substrate that can temporarily accelerate growth of the planktonic actinobacterial phylotypes. Alternatively, the composition of EPP released by diatoms may not provide the competitors of Actinobacteria with substrates allowing them to maintain population growth rate.

Overall, the present study significantly contributes to the knowledge of specific aspects of the highly complex interplay between major top-down and bottom-up factors affecting spatio-temporal development of bacterioplankton of canyon-shaped reservoirs that have recently become, due to their high degree of heterogeneity, a target of numerous studies (cf. Šimek et al. 1998, 2005, Gasol et al. 2002, Comerma et al. 2003, Mašín et al. 2003). The analysis of the data on phytoplankton composition in relation to the observed shifts in bacterioplankton composition indicates a strong, taxon-specific algal-bacterial relationship and points to the need for further studies with finer taxonomic resolution allowing the elucidation of major phytoplankton-related eco-physiological traits of the relevant bacterioplankton species.

Acknowledgements. This study was largely supported by the Grant Agency of the Czech Republic under research grants 206/08/0015 and 206/05/0007 awarded to K.S.., by the Academy of Sciences project nos. AV0Z 60170517 and 1QS600170504 and partially also by project MSM 600766 5801. We wish to thank J. Dolan for valuable comments and English correction, and S. Smrčková and R. Malá for excellent technical assistance.

\section{LITERATURE CITED}

Baines SB, Pace ML (1991) The production of dissolved organic matter by phytoplankton and its importance to bacteria: patterns across marine and freshwater systems. Limnol Oceanogr 36:1078-1090

Berninger UG, Finlay BJ, Kuuppo-Leinikki P (1991) Protozoan control of bacterial abundances in freshwaters. Limnol Oceanogr 36:139-147

Burkert U, Warnecke F, Babenzien D, Zwirnmann E, Pernthaler J (2003) Members of a readily enriched $\beta$-proteobacterial clade are common in surface waters of a humic lake. Appl Environ Microbiol 69:6550-6559

Comerma M, García JC, Romero M, Armengol J, Šimek K (2003) Carbon flow dynamics in the pelagic community of the Sau Reservoir (Catalonia, NE Spain). Hydrobiologia 504:87-98

Descy JP, Leporcq B, Viroux L, Francois C, Servais P (2002) Phytoplankton production, exudation and bacterial reassimilation in the River Meuse (Belgium). J Plankton Res 24:161-166

Gasol JM, Comerma M, García JC, Armengol J, Casamayor EO, Kojecká P, Šimek K (2002) A transplant experiment to identify the factors controlling bacterial abundance, activity, production, and community composition in a 
eutrophic canyon shaped reservoir. Limnol Oceanogr 47:62-77

Geller W, Müller H (1981) The filtration apparatus of Cladocera: filter mesh-sizes and their implications on food selectivity. Oecologia 49:316-321

Giroldo D, Ortolano PIC, Vieira AAH (2007) Bacteria-algae association in batch cultures of phytoplankton from a tropical reservoir: the significance of algal carbohydrates. Freshw Biol 52:1281-1289

Grossart HP, Levold F, Allgaier M, Simon M, Brinkhoff T (2005) Marine diatom species harbour distinct bacterial communities. Environ Microbiol 7:860-873

Hahn MW (2003) Isolation of strains belonging to the cosmopolitan Polynucleobacter necessarius cluster from freshwater habitats located in three climatic zones. Appl Environ Microbiol 69:5248-5254

Hahn MW, Pöckl M (2005) Ecotypes of planktonic Actinobacteria with identical 16S rRNA genes adapted to thermal niches in temperate, subtropical, and tropical freshwater habitats. Appl Environ Microbiol 71:766-773

> Hahn MW, Pöckl M, Wu QL (2005) Low intraspecific diversity in a Polynucleobacter subcluster population numerically dominating bacterioplankton of a freshwater pond. Appl Environ Microbiol 71:4539-4547

Horňák K, Jezbera J, Nedoma J, Gasol JM, Šimek K (2006) Effects of resource availability and bacterivory on leucine incorporation in different groups of freshwater bacterioplankton, assessed using microautoradiography. Aquat Microb Ecol 45:277-289

> Hygum BH, Petersen JW, Søndergaard M (1997) Dissolved organic carbon released by zooplankton grazing activity - a high-quality substrate pool for bacteria. J Plankton Res 19:97-111

Jardillier L, Basset M, Domaizon I, Belan A, Amblard C, Richardot M, Debroas D (2004) Bottom-up and top-down control of the bacterial community composition in the euphotic zone of a reservoir. Aquat Microb Ecol 35: 259-273

Jezbera J, Nedoma J, Šimek K (2003) Longitudinal changes in protistan bacterivory and bacterial production in two differently loaded canyon-shaped reservoirs. Hydrobiologia 504:115-130

Jezbera J, Horňák K, Šimek K (2005) Food selection by bacterivorous protists: insight from the analysis of the food vacuole content by means of fluorescence in situ hybridization. FEMS Microbiol Ecol 52:351-363

Jürgens K (1994) Impact of Daphnia on planktonic microbial food webs. A review. Mar Microb Food Webs 8:295-324

Kirchman DL (2002) The ecology of Cytophaga-Flavobacteria in aquatic environments. FEMS Microbiol Ecol 39:91-100

Kopáček J, Hejzlar J (1993) Semi-micro determination of total phosphorus in fresh waters with perchloric acid digestion. Int J Environ Anal Chem 53:173-183

> Lancelot C (1983) Factors affecting phytoplankton extracellular release in the Southern Bight of the North Sea. Mar Ecol Prog Ser 12:115-121

> Larsson U, Hagström Å (1982) Fractionated phytoplankton primary production, exudate release and bacterial production in a Baltic eutrophication gradient. Mar Biol 67:57-70

Lindström ES (2000) Bacterioplankton community composition in five lakes differing in trophic status and humic content. Microb Ecol 40:104-113

Lindström ES (2001) Investigating influential factors on bacterioplankton community composition: results from a field study of five mesotrophic lakes. Microb Ecol 42:598-605

Lorenzen CJ (1967) Determination of chlorophyll and phaeopigments: spectrophotometric equation. Limnol Oceanogr 12:343-346
Mašín M, Šimek K, Jezbera J, Nedoma J, Straškrabová V, Hejzlar J (2003) Changes in bacterial community composition and microbial activities along the longitudinal axis of two differently loaded canyon-shaped reservoirs. Hydrobiologia 504:99-113

McCauley E (1984) The estimation of the abundance and biomass of zooplankton samples. In: Downing JA, Rigler FH (eds) A manual on methods for the assessment of secondary productivity in fresh waters. Blackwell Publications, Oxford, p 228-265

Murphy J, Riley JP (1962) A modified single-solution method for the determination of phosphate in natural waters. Anal Chim Acta 27:31-36

Murray AE, Arnosti C, De La Rocha CL, Grossart HP, Passow U (2007) Microbial dynamics in autotrophic and heterotrophic seawater mesocosms. II. Bacterioplankton community structure and hydrolytic enzyme activities. Aquat Microb Ecol 49:123-141

Nedoma J, Porcalová P, Komárková J, Vyhnálek V (1993) Phosphorus deficiency diagnostics in the eutrophic Rímov reservoir. Water Sci Technol 28:75-84

Pace ML, McManus GB, Findlay SEG (1990) Planktonic community structure determines the fate of bacterial production in a temperate lake. Limnol Oceanogr 35:795-808

Pérez MT, Sommaruga R (2006) Differential effect of algaland soil-derived dissolved organic matter on alpine lake bacterial community composition and activity. Limnol Oceanogr 51:2527-2537

> Pernthaler A, Pernthaler J, Amann R (2002) Fluorescence in situ hybridization and catalyzed reporter deposition for the identification of marine bacteria. Appl Environ Microbiol 68:3094-3101

Posch T, Pernthaler J, Alfreider A, Psenner R (1997) Cellspecific respiratory activity of aquatic bacteria studied with the tetrazolium reduction method, cyto-clear slides and image analysis. Appl Environ Microbiol 63: 867-873

Posch T, Jezbera J, Vrba J, Šimek K, Andreatta S, Sonntag B (2001) Size selective feeding in Cyclidium glaucoma (Ciliophora, Scuticociliatida) and its effects on bacterial community structure: a study from a continuous cultivation system. Microb Ecol 42:217-227

Richman S, Dodson SI (1983) The effect of food quality on feeding and respiration by Daphnia and Diaptomus. Limnol Oceanogr 28:948-953

Riemann B, Søndergaard M (1986) Carbon dynamics in eutrophic, temperate lakes. Elsevier Science Publishers, Amsterdam

Sed'a J, Kolářová K, Petrusek A, Macháček J (2007) Daphnia galeata in the deep hypolimnion: spatial differentiation of a 'typical epilimnetic' species. Hydrobiologia 594:47-57

Senft WH (1978) Dependence of light-saturated rates of algal photosynthesis on intracellular concentrations of phosphorus. Limnol Oceanogr 23:709-718

Šimek K, Vrba J, Pernthaler J, Posch T, Hartman P, Nedoma J, Psenner R (1997) Morphological and genotypic shifts in an experimental bacterial community influenced by protists of contrasting feeding modes. Appl Environ Microbiol 63:587-595

Šimek K, Armengol J, Comerma M, Garcia JC and others (1998) Characteristics of protistan control of bacterial production in three reservoirs of different trophy. Int Rev Hydrobiol 83(Spec Issue):485-494

Šimek K, Pernthaler J, Weinbauer HG, Horňák K and others (2001) Changes in bacterial community composition, dynamics and viral mortality rates associated with enhanced flagellate grazing in a meso-eutrophic reservoir. Appl Environ Microbiol 67:2723-2733 
Šimek K, Horňák K, Jezbera J, Mašín M, Nedoma J, Gasol JM, Schauer M (2005) Influence of top-down and bottom-up manipulations on the R-BT065 subcluster of $\beta$-proteobacteria, an abundant group in bacterioplankton of a freshwater reservoir. Appl Environ Microbiol 71: 2381-2390

Šimek K, Horňák K, Jezbera J, Nedoma J and others (2006) Maximum growth rates and possible life strategies of different bacterioplankton groups in relation to phosphorus availability in a freshwater reservoir. Environ Microbiol 8:1613-1624

Simon M, Grossart HP, Schweitzer B, Ploug H (2002) Microbial ecology of organic aggregates in aquatic ecosystems. Aquat Microb Ecol 28:175-211

Straškrabová V, Callieri C, Carrillo P, Cruz-Pizarro L and others (1999) Investigations on pelagic food webs in mountain lakes - aims and methods. J Limnol 58:77-87

Sundh I (1992) Biochemical composition of dissolved organic carbon derived from phytoplankton and used by heterotrophic bacteria. Appl Environ Microbiol 58:2938-2947

Thornton KW, Kimmel BL, Payne FE (1990) Reservoir limnol-

Editorial responsibility: Robert Sanders,

Philadelphia, Pennsylvania, USA ogy: ecological perspectives. Wiley \& Sons, New York

> Weinbauer M, Nedoma J, Christaki U, Šimek K (2003) Comparing the effects of resource enrichment and grazing on viral production in a meso-eutrophic reservoir. Aquat Microb Ecol 31:137-144

Wu QL, Hahn MW (2006) High predictability of the seasonal dynamics of a species-like Polynucleobacter population in a freshwater lake. Environ Microbiol 8:1660-1666

Znachor P, Nedoma J (2008) Application of the PDMPO technique in studying silica deposition in natural populations of Fragilaria crotonensis (Bacillariophyceae) at different depths in a eutrophic reservoir. J Phycol 44:518-525

> Zwart G, Crump BC, Kamst-van Agterveld MP, Hagen F, Han SK (2002) Typical freshwater bacteria: an analysis of available 16S rRNA gene sequences from plankton of lakes and rivers. Aquat Microb Ecol 28:141-155

Zwart G, van Hannen EJ, Kamst-van Agterveld MP, Van der Gucht K and others (2003) Rapid screening for freshwater bacterial groups by using reverse line blot hybridization. Appl Environ Microbiol 69:5875-5883

Submitted: December 11, 2007; Accepted: March 12, 2008 Proofs received from author(s): May 23, 2008 